Review

\title{
Enteroviruses and T1D: Is It the Virus, the Genes or Both which Cause T1D
}

\author{
Shirin Geravandi ${ }^{+}$iD, Huan Liu ${ }^{\dagger}$ and Kathrin Maedler* ${ }^{\mathbb{D}}$ \\ Centre for Biomolecular Interactions Bremen, University of Bremen, 28359 Bremen, Germany; \\ geravand@uni-bremen.de (S.G.); liuhuan2012@yahoo.com (H.L.) \\ * Correspondence: kmaedler@uni-bremen.de; Tel.: +49-(421)-218-63290 \\ + Contributed equally.
}

Received: 15 June 2020; Accepted: 6 July 2020; Published: 8 July 2020

\begin{abstract}
Type 1 diabetes (T1D) is a chronic autoimmune disorder that results from the selective destruction of insulin-producing $\beta$-cells in the pancreas. Up to now, the mechanisms triggering the initiation and progression of the disease are, in their complexity, not fully understood and imply the disruption of several tolerance networks. Viral infection is one of the environmental factors triggering diabetes, which is initially based on the observation that the disease's incidence follows a periodic pattern within the population. Moreover, the strong correlation of genetic susceptibility is a prerequisite for enteroviral infection associated islet autoimmunity. Epidemiological data and clinical findings indicate enteroviral infections, mainly of the coxsackie B virus family, as potential pathogenic mechanisms to trigger the autoimmune reaction towards $\beta$-cells, resulting in the boost of inflammation following $\beta$-cell destruction and the onset of T1D. This review discusses previously identified virus-associated genetics and pathways of $\beta$-cell destruction. Is it the virus itself which leads to $\beta$-cell destruction and T1D progression? Or is it genetic, so that the virus may activate auto-immunity and $\beta$-cell destruction only in genetically predisposed individuals?
\end{abstract}

Keywords: type 1 diabetes; enterovirus; coxsackievirus; beta-cell; HLA; IF1H1; TLR3; IFIH1; YAP; Hippo

\section{Introduction}

T1D (type 1 diabetes) results from a complex interplay of a multi-genetic predisposition and environmental factors. We have read similar phrases before which are valid for numerous diseases and pathological mechanisms. Saying this is the same for diabetes as well as for any other autoimmune disease: (1) we do not really know what the real cause of the disease is and (2) apparently, there is no single cause for the disease. Thus, this phrase does describe T1D: it results from multiple triggers, which makes the disease very complex. Research has been able to identify many drivers of the disease in the past, such as the initiation of autoimmunity, paths of $\beta$-cell destruction, genetic mutations associated with the one (autoimmunity) or the other ( $\beta$-cell death), or both [1-5].

However, we are still seeking the salient event which finally, through multiple cascades, leads to $\beta$-cell failure, loss in insulin production and secretion and, subsequently, hyperglycemia. Protection of the $\beta$-cell and prevention of diabetes before its clinical manifestation can be achieved only if the initiators are identified.

What we also know from intensive research is that T1D is a heterogeneous disease. Over the past decades, childhood T1D has increased worldwide at an estimated average annual rate of $3.9 \%$; such doubling during the last 20 years is too high to result only from genetic causes [5-7]. Firstly, the concordance rate between monogenetic twins is only about 50\% [8]. Secondly, epidemiological 
studies have shown that the disease's incidence follows a periodic pattern within the population $[5,6,9]$ with a significant geographical variation [6].

Support of a putative role for viral infections in the development of T1D comes from epidemiological studies, which have uncovered the seasonal pattern of disease presentation after enterovirus epidemics [6]. Specifically, enteroviruses have been made responsible as an initiator of autoimmunity as well as $\beta$-cell failure from epidemiological, pathological and in vitro studies [10-12].

Virus pathology per se commonly shows heterogeneity in its outcome, as it causes severe disease only in some affected patients. The current SARS-CoV2 pandemic in 2019/2020 is an overwhelming example of the array of outcomes of virus infection in different people, depending, e.g., on age, genetic background and pre-existing disease, from asymptomatic to pathologic [13]. There is a bidirectional relationship between Covid-19 and diabetes [14]. Firstly, several rapid communications have associated SARS-CoV2 with acute-onset diabetes [14,15], and, secondly, patients with diabetes are at greater risk for severe Covid-19 illness.

Obviously, T1D is not an acute infectious viral disease, as scenarios of massive infection in the pancreas have never been observed in T1D. The virus is lytic to $\beta$-cells in vitro, but such has not been detected in vivo, where rather a persistent infection may trigger the immune response. Most of us have had an asymptomatic enteroviral infection during childhood which did not end up causing T1D. With their positive-sense single stranded RNA genome, coxsackieviruses from the family of picornaviridae are widely spread viruses all over the world ranging from $7-22 \%$ in Greece and up to $50 \%$ and $80 \%$ in Montreal and in parts of China, respectively [16]. They most commonly cause hand-foot-and-mouth disease, producing flu-like symptoms, but also have the ability to infect the pancreas, heart and CNS.

Together with an environmental factor, an additional factor is needed to potentiate the susceptibility to enteroviral infections to finally trigger autoimmunity and $\beta$-cell destruction, i.e., a certain genetic predisposition. Mutations have been found to either impair virus clearance upon infection, or, oppositely, to increase viral response by inducing a storm of cytokines, which will then destroy the $\beta$-cells which are vulnerable to inflammation.

\section{Seasonal Patterns of Viral and Autoimmune Diseases}

More than 60 infectious diseases have been associated with seasonal patterns, identified by a systematic search for "seasonality" from a list of communicable diseases from the Centers for Disease Control and Prevention (CDC), World Health Organization (WHO), and the European Centre for Disease Prevention and Control [17]. The flu season in the winter of the Northern Hemisphere is the most classic. As enteroviruses and especially coxsackieviruses have multiple serotypes, they cause a broad spectrum of diseases and peak at different times; however, clear seasonality has also been reported for Coxsackie B3 and B4 [17,18].

The seasonal drive is complex and multifarious. There is not only the seasonal viral exposure, but also environmental conditions such as climate (temperature, hours of daylight and sunshine) and human seasonal behavioral, i.e., diet and exercise, which reflects on the host's immune system status and makes us more prone to infection, e.g., to flu in the winter.

In the similar way, most autoimmune diseases "go viral" seasonally, e.g., T1D, multiple sclerosis (MS), systemic lupus erythematosus (SLE), psoriasis, and rheumatoid arthritis (RA), inflammatory bowel diseases (IBD), autoimmune liver diseases (ALDs), autoimmune thyroid disease (AITD), coeliac disease, Sjögren's syndrome (SS) and systemic sclerosis (SSc) [19]. First reported by Franklin Adams in 1926, disease breaks out in the winter season "immediately after such an infection" [9], and this has been later confirmed in large studies [20-22]. T1D diagnosis peaks in the colder months of late autumn to early spring, while it drops in the summer. Such seasonality disappears in regions closer to the equator. Unfortunately, sparse epidemiological data are available from equatorial regions [23], which do not allow any speculation on differences in the T1D incidence per se. 
In the Finish DIPP cohort study, the appearance of autoantibodies showed a seasonal pattern with a significantly higher proportion in the fall and winter [24]. Thus, autoimmunity follows the same pattern as viral infection and may not just be directly caused by virus infection, but rather by a combination of unfavorable events at the same time, i.e., higher inflammation in the winter, when diet often changes to sweeter and fattier food with less exercise outside and low vitamin D levels because of limited sunlight exposure, which are all factors that have been independently shown to be associated with T1D [19] (Figure 1). Furthermore, there is the increased risk for another auto-immune disease [25].

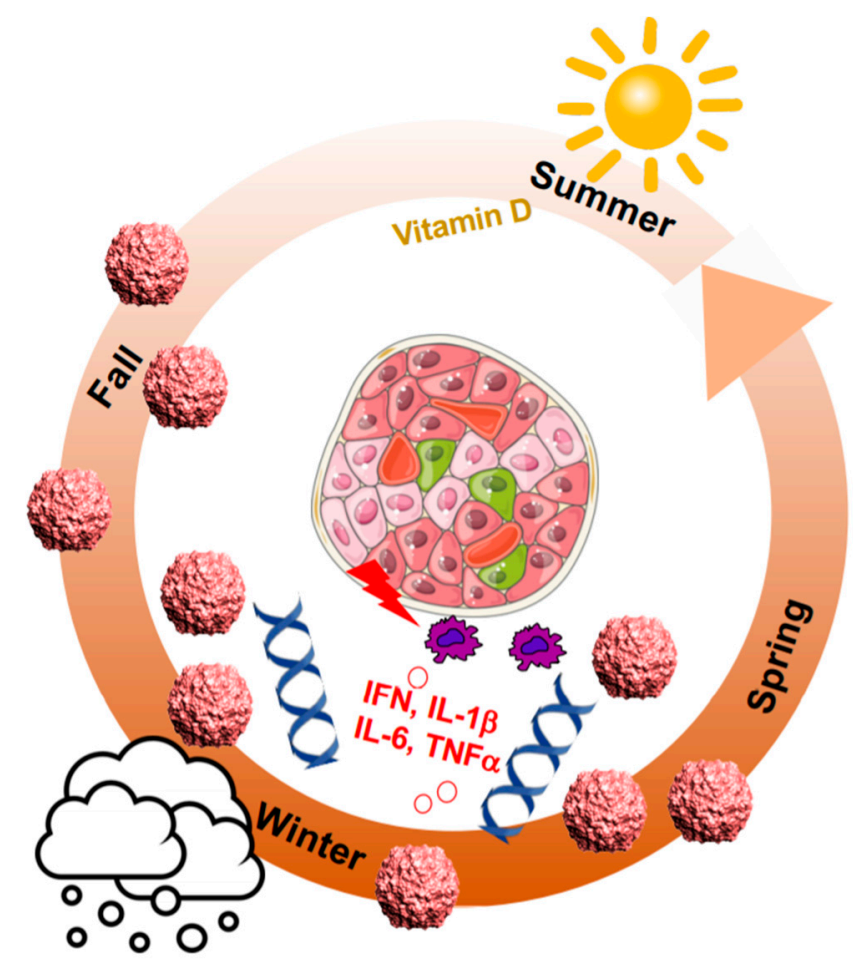

Figure 1. Not only environmental factors but also gene regulation show seasonal patterns. T1D (type 1 diabetes) diagnosis peaks in the colder months of late autumn to early spring, where viral infections come together with less sunlight exposure, less exercise outside, a change in diet together with an increase in pro-inflammatory cytokines and a change towards pro-inflammatory gene networks.

Each of the single factors as a sole initiator for autoimmunity and T1D have been debated and thus, such single factor is unlikely to cause T1D. Early studies from Finland within the DiMe and DIPP cohorts have shown the association of enterovirus infection with autoimmunity and T1D [26-29], while this is not supported by previous results from the DAISY [30] and BABYDIAB [31] cohorts. Another example comes from vitamin $\mathrm{D}$ : while several studies show a correlation of lower levels of vitamin $\mathrm{D}$ with the onset of T1D [25,32], this was not confirmed by others, and several formulations of vitamin D supplementation could not reduce disease progression [33]. Crucially, it may be the seasonal change in vitamin D metabolism together with changes in the expression of its vitamin D receptor [34] that serve as the additional factors for autoimmune disease predisposition. Using large gene expression datasets from the German BABYDIET, Australia, United Kingdom/Ireland, United States and Iceland cohorts, a previous study also shows seasonal patterns in gene regulation [34]. Gene expression of both the vitamin D receptor and the anti-inflammatory circadian clock regulator transcription factor, BMAL1 (ARNTL1), is lowest in the winter [34], which promotes inflammation through increased levels of soluble IL-6 receptor and C-reactive protein [34]. Several studies in mice and isolated islets show that BMAL1 depletion impairs $\beta$-cell survival and disturbs a coordinated insulin secretion which may trigger the onset of diabetes due to defective $\beta$-cell function $[35,36]$. Conversely, BMAL1 is severely 
depleted in islets from patients with type 2 diabetes (T2D) and disrupted by IL-1 $\beta$ exposure of islets in vitro [37]. This suggests a direct causative role for depleted BMAL1 in inflammation and $\beta$-cell failure. Physiologically, the circadian clock would inhibit inflammation and also prevent the cell from hypoxia, as shown in the heart [38]. Thus, reduction in BMAL1 disables the cellular antioxidant response and increases HIF- $1 \alpha$ and ROS accumulation in immune cells, which would further induce the production of proinflammatory cytokines, i.e., TNF $\alpha$, IL-1 $\beta$ [39] from macrophages, dendritic cells as well as from $\beta$-cells themselves $[40,41]$. The direct cross-talk of transcription factors regulating clock genes (BMAL; ARNTL1) and hypoxia (HIF1 $\alpha$; ARNT) can have fatal consequences. Both belong to same family of PAS-domain, helix-loop-helix transcription factors and share some overlapping DNA binding sites [38,42]. HIF-1 $\alpha$ mutations have not only been shown for T1D but also for many other autoimmune diseases [43] and thus again link seasonal changes with genetic predisposition for autoimmune disease. This is especially deleterious for the $\beta$-cell with its very low expression of antioxidants and high expression of cytokine and Toll-like receptors [44]. Any increased inflammation may predispose a body to $\beta$-cell failure, and thus it may not be the seasonal virus spread alone which causes auto-immunity but rather the pro-inflammatory environment in the host which potentiates $\beta$-cell failure with subsequent diabetes initiation. As such, this may only happen in genetically predisposed individuals. All three events together (viruses, the pro-inflammatory milieu in the host and the genetic profile) and their seasonality in their regulation may then initiate $\beta$-cell failure and auto-immunity.

\section{HLA Class I and Class II Are Major Determiners for T1D}

The strongest genetic risk factors for T1D are located in the major histocompatibility complex (MHC, also called the human leukocyte antigen: HLA) class II on chromosome 6, with the predisposing HLA class II haplotypes found in around $90 \%$ of patients with T1D [45]; the specific combination of HLA II alleles HLA-DRB1*03 (DR3) or HLA-DRB1*04 (DR4) with DQB1*03:02 (DQ8) confer the highest risk for T1D (for details on HLA susceptibility please see an excellent previous review [46]).

In addition, susceptibility loci also in the HLA I region contribute to T1D [46-48] and their direct association with the age of T1D onset has been shown in several studies $[46,47,49]$. Predisposing alleles correlate with a younger age, and a protective allele with an older age at onset [47]. Children diagnosed at a very young age usually have a more severe T1D than those diagnosed as teenagers or young adults. Early T1D onset ( $\leq 5$ years) can predict T1D severity, especially for diabetic complications such as retinopathy [50]. One could assume from these studies that the predisposing HLA class I alleles do not only correlate with age, but also with diabetes severity, although this has not been directly addressed in previous studies. For a possible similar correlation of HLA class II risk alleles with age of onset or severity of disease, only few study results are available. Valdes et al. reported that a DRB1-DQB1 HLA class II at risk allele contributes to the age at onset of T1D. However, a pure prediction of the disease onset from HLA alleles alone has been difficult among populations, since many more factors and their combination, i.e., T1D genetics and auto-antibodies play a major role [47].

The very early appearance of asymptomatic autoimmunity and its strong relationship with age and disease severity was found in all the large prospective T1D studies: BABYDIAB, DIPP (Diabetes Prediction and Prevention) and TEDDY (The Environmental Determinants of Diabetes in the Young). It is detected by any of the ICA, IAA, GAD, IA-2 and ZnT8 auto-antibodies and follows the exponential decay model starting in the first year of life in genetically at-risk children in affected families with first-degree relatives with T1D (FDR). Indeed, children who developed autoimmunity in the first year of life had the highest risk of T1D [51], which is further increased in those children with the high-risk HLA-DR3-DR4-DQ8 or DR4-DQ8/DR4-DQ8 genotypes [24,51].

The strong correlation of HLA-genetic susceptibility as a prerequisite for enteroviral infection-associated islet autoimmunity was depicted many years ago in the Finish DiMe study: children with a high-risk HLA allele converted to ICA positivity during enteroviral infection more often than those without HLA risk [27]. Further results from the DiMe (Childhood Diabetes in Finland) 
and DIPP studies show increased islet auto-antibody appearance with enterovirus infections during pregnancy and early childhood and their correlation to T1D progression [27-29].

Confirmed in all three major T1D pancreatic tissue biobanks (EADB, Exeter Archival Diabetes Biobank; DiViD, Diabetes Virus Detection Study; and nPOD, Network for Pancreatic Organ Donors with Diabetes), the age of onset determines the number of cases with any left residual beta-cells, i.e., an older age of T1D onset strongly correlates with more remaining $\beta$-cells and children with diabetes onset $<7$ years have fewer $\beta$-cells left than at the onset $7-12$, and again fewer than those diagnosed at $>13$ years [52]. Usually seen near disease onset, i.e., within the first 7 years of diagnosis and found located and "hyperexpressed" on the surface of $\beta$-cells in T1D [53], HLA I molecules present antigens to activated cytotoxic CD8 T-cells which then lead to islet infiltration and all together to subsequent $\beta$-cell destruction (Figure 2). It is therefore possible that such HLA I hyperexpression may coincide with $\beta$-cell failure. Although the stimulus for $\beta$-cell specific HLA I hyperexpression in vivo is not clear yet, it is often associated with enteroviral infection, indirectly reported based on viral capsid protein immunofluorescence in insulin containing islet (ICI) clusters [52] as well as insulitis. Histological analyses of the human T1D pancreas show all, viral capsid VP1, IFN $\alpha$, the major cytokine induced by viral infection, and HLA I expressed in or within the islet proximity $[52,53]$. Mechanistically shown in islets in vitro, enterovirus-induced IFN $\alpha$ [54] leads to $\beta$-cell upregulation of HLA class I $[55,56]$. IFN $\alpha$-mediated HLA class I induces inflammation and ER stress, but is alone insufficient to cause beta-cell apoptosis. Additional exposure of islets to the pro-inflammatory cytokine IL-1 $\beta$ potentiates $\beta$-cell apoptosis [56], suggesting the necessity of a complex pro-inflammatory milieu to induce $\beta$-cell failure.

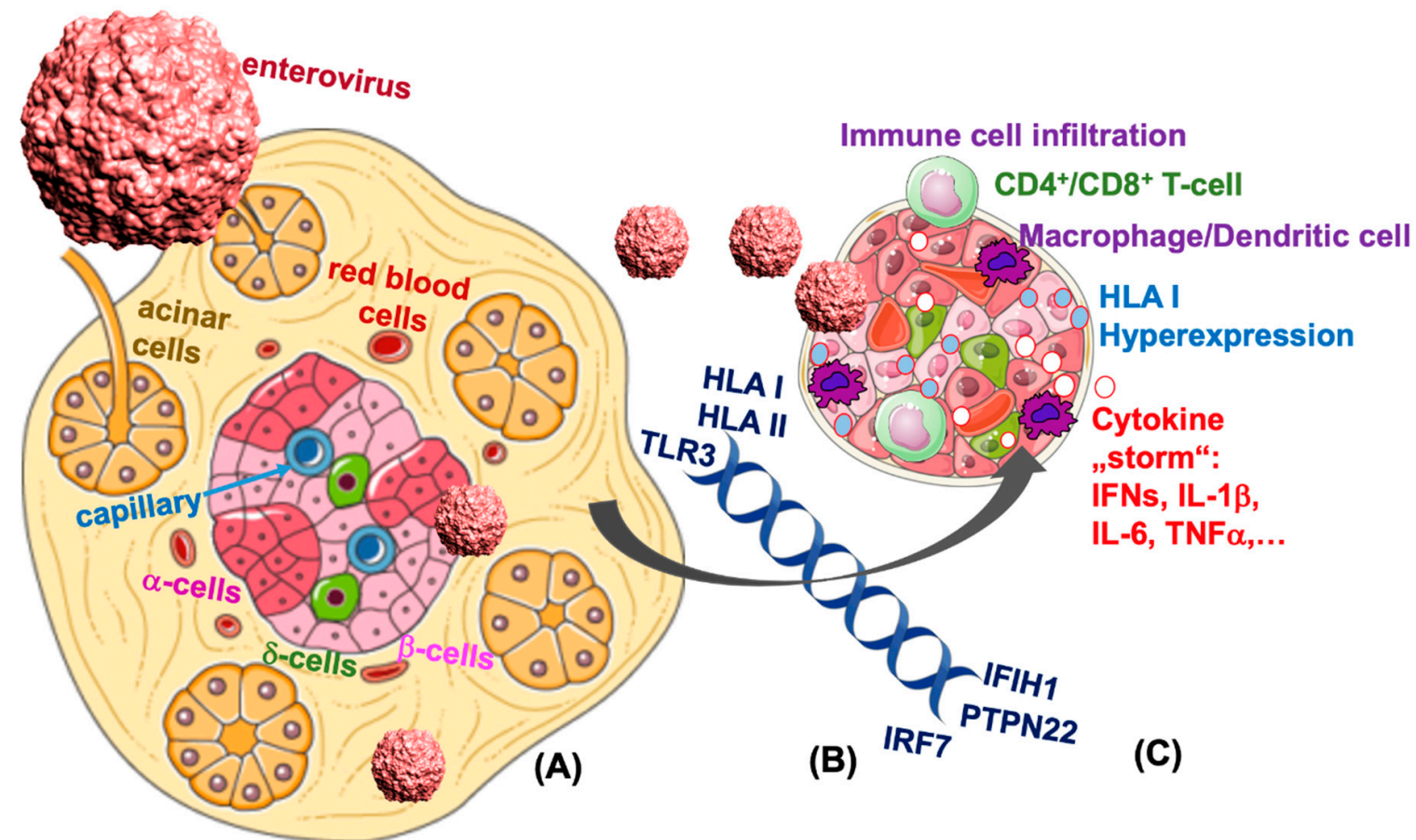

Figure 2. $\beta$-cell destruction in T1D is associated with viral response pathways. $\beta$-cells are highly vulnerable to enteroviral infection. (A) Several genetic mutations in the viral response pathway in T1D may lead to the potentiation in viral response. (B) A consequent "storm" of pro-inflammatory cytokines and chemokines lead to HLA I hyperexpression and attract cytotoxic T-cells and macrophages and subsequently to the loss of $\beta$-cells (C) and manifestation of T1D.

It is important to note that the association of HLA was not only identified for T1D, but for many other autoimmune diseases, i.e., rheumatoid arthritis, celiac disease and multiple sclerosis $[19,57]$ which assumes that (i) physiological HLA is a prerequisite for a balanced immune regulation and (ii) 
enteroviral infections may lead to disturbance of such balance, through attraction of activated T-cells towards the virus' homing tissue.

Based on these large studies, islet autoimmunity in early life is indeed related to genetic factors and disease severity. The propensity of a very young child, i.e., $<1$ year to respond to environmental factors such as enteroviruses may thereby potentiate the risk to T1D progression.

\section{Direct Evidence for Enteroviral RNA in the Pancreas}

Epidemiological data and clinical findings show a correlation between enterovirus infection and the onset of T1D [6,58]. In 1969, Taylor's lab reported the presence of neutralizing anti-coxsackievirus B4 antibodies in the serum of patients with T1D [59]. Since then, enterovirus infections, mainly of the coxsackie B virus (CVB) family, were hypothesized as a potential pathogenic mechanism to trigger the autoimmune reaction to $\beta$-cells, resulting in the destruction of $\beta$-cells $[54,60]$ and the onset of T1D [61,62]. Following the isolation of CVB4 from a pancreas autopsy of a 10-year-old boy with T1D [63], many large studies tried to identify the virus directly from the T1D pancreas.

In newly diagnosed T1D patients of the DiViD study (3-9 weeks after T1D onset), VP1 was detected in biopsy pancreases in all patients in $1.7 \%$ of the islets. It is possible that such a $100 \%$ correlation of VP1 and T1D was observed because of a higher expression at diagnosis, which would decline at later stages [64], however such a hypothesis would need to be experimentally proven. Furthermore, HLA I expression was found in all patients. Viral RNA in the frozen pancreas was only found in one T1D patient and from cultured enriched islets in only 4 of 6 patients at a very low concentration (by PCR, $>40$ cycles), which shows no evidence of an acute but, if any, rather a low-grade infection. In confirmation with several previous studies [65], classical RT-PCR was not sensitive enough for the analysis of a viral infection, which only occurs in few cells within the whole pancreas. RNA sequencing from the whole pancreas could not identify any viral sequences, again suggesting the threshold of the presence of viral sequences compared to all other genes as sparse to be identified by classical RNASeq methods. Nevertheless, several approaches have confirmed the presence of enteroviruses both in the circulation and in islets of T1D patients [64,66-70], however, because of a very low expression, many attempts have failed to characterize the localization and the specific enteroviral sequences through PCR-based methods in the pancreas.

Enrichment strategies are necessary to detect such low-grade infection, e.g., amplification of viruses by preculturing human leucocytes from patients with T1D and subsequent RT-PCR analysis [71] or by the elegant viral-capture sequencing methods in which viral sequences are enriched before sequencing, that enable the identification of enteroviruses in stool samples from islet auto-antibody positive children [72].

Viruses that have a specific tropism within the islets could cause the onset of the disease not only by direct cytolysis but also by triggering the host immune response [73]. The presence of several CVB viruses, including CVB4, together with the Coxsackie-adenovirus receptor (CAR) in the $\beta$-cell, support the connection of viral infection with T1D. Coxsackieviruses induce a persistent, slowly-replicating infection; this may result from alterations to the viral genome during the progress of infection, such as naturally occurring $5^{\prime}$-deletions [74-76]. Because of several such limitations to the detection of enteroviruses, we have previously established an adapted method to target single RNA molecules with short ( 20 nucleotides) fluorescently labeled oligonucleotides in situ. Probes consist of a mixture of 40 short oligonucleotides covering the whole length of the viral genome and anneal to common regions of the RNA genome of the coxsackievirus family [77]. This enables targeting single RNA molecules. Short labeled oligo RNA probes are more resistant to RNAse, and RNA detection is less affected by target RNA degradation and fragmentation. Through the availability of the well-characterized cohort of human pancreatic donor tissue established by nPOD [78], viral mRNA can be detected in the T1D pancreas with high sensitivity, specificity and accuracy and at lower viral loads than by classical immunostaining and even PCR $[77,79]$. Further ongoing studies of pancreas sections revealed 
remarkable significance of viral RNA expression in T1D pancreata, compared to controls without T1D [80].

Using this method, we have analyzed whole pancreas sections and quantified enteroviral mRNA by unbiased scans and identified viral mRNA distributed not specifically within or in proximity to islets; enteroviral mRNA was evident through individual dots in single cells throughout the pancreas (Figure 3). Such observation is in contrast to VP1 immunohistochemistry in the pancreas [81], which mostly detected VP1 positivity in or near islets. Famously referred to as the "streetlight effect" [82], it is difficult to find what we search for in the dark, and thus, it is possible that several antibody-based stainings were preferentially observed in islets, although the staining has been carefully re-evaluated and VP1 correlates with hyperexpression of HLA class I in islets [83]. The commonly used DAKO-VP1-Ab detects several other antigens in addition to VP1 and/or exocrine enzymes may degrade enteroviral proteins and thus prevent their detection in the pancreas [84].

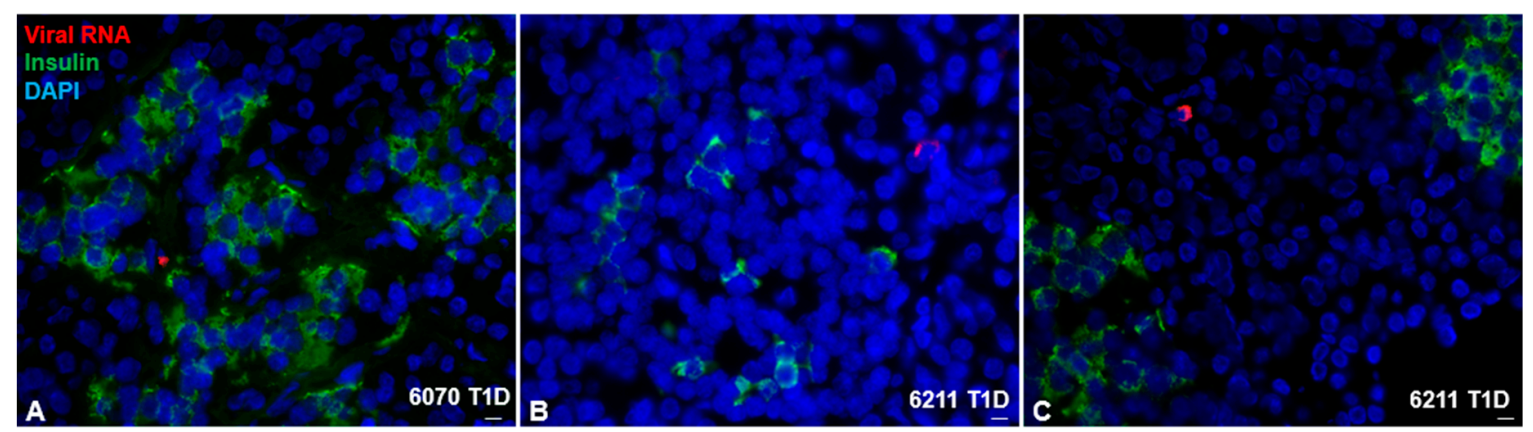

Figure 3. Coxsackieviral RNA in the T1D pancreas. Representative images of T1D donors 6070 and 6211 from the nPOD cohort. Viral RNA was found within the endocrine area $(\mathbf{A})$ and outside the islets $(\mathbf{B}, \mathbf{C})$ shown by co-staining of viral RNA probes (red), insulin (green) and DAPI (nuclei; blue). Tissues were first probed for viral RNA, and then stained for insulin after a previously established protocol ([77]; Busse et al.). Scale bar depicts $10 \mu \mathrm{m}$.

Early studies, where C57BL/6 mice were infected with CVB3, also observed viral infection localization in the pancreas in the acinar cells, together with severe inflammation and acinar cell destruction [85]. Despite the well-known differences in enteroviruses' tropism in the pancreas in mice and humans [85], such observation is in line with the decreased acinar cell number and acinar tissue mass reported in numerous studies from human T1D pancreases [86-88].

Rather than from the virus itself, $\beta$-cell destruction may result from "bystander" damage [89,90], where coxsackie virus infection may lead to a storm of inflammation in cells like the $\beta$-cell, which carry an enormous amount of pattern recognition (such as TLR3 and TLR4), cytokine (such as IL-1R1), and chemokine receptors on their surface [44]. Their activation by viruses and by cellular viral responses stop viral replication on one hand, but induce tissue damage on the other. In addition, interferons accelerate expression of surface HLA-I molecules and thus activation of auto-reactive T-cells against $\beta$-cells (Figures 2 and 4). T-cell activation through non-T-cell receptors ("bystander damage") [89] is limited to viral infection [91], where $\beta$-cell apoptosis is triggered by viral response products, e.g., cytokines and chemokines [92]. Such a pro-inflammatory environment has also been shown to alter the composition of the islet extracellular matrix, which may further facilitate T-cell migration towards pancreatic islets [93]. The specific and severe $\beta$-cell destruction then occurs through their special vulnerability towards an array of cytokines and chemokines such as interleukin (IL)-1 $\beta$, interferon (IFN)- $\gamma$, tumor necrosis factor (TNF)- $\alpha$ and CXCL10 [94], which induce $\beta$-cell destruction in response to viral infection in human islets $[60,95]$ (Figure 4). It is also possible that multiple infections during childhood each time contribute to potentiating the immune response and then lead to $\beta$-cell destruction, autoimmunity and T1D. 


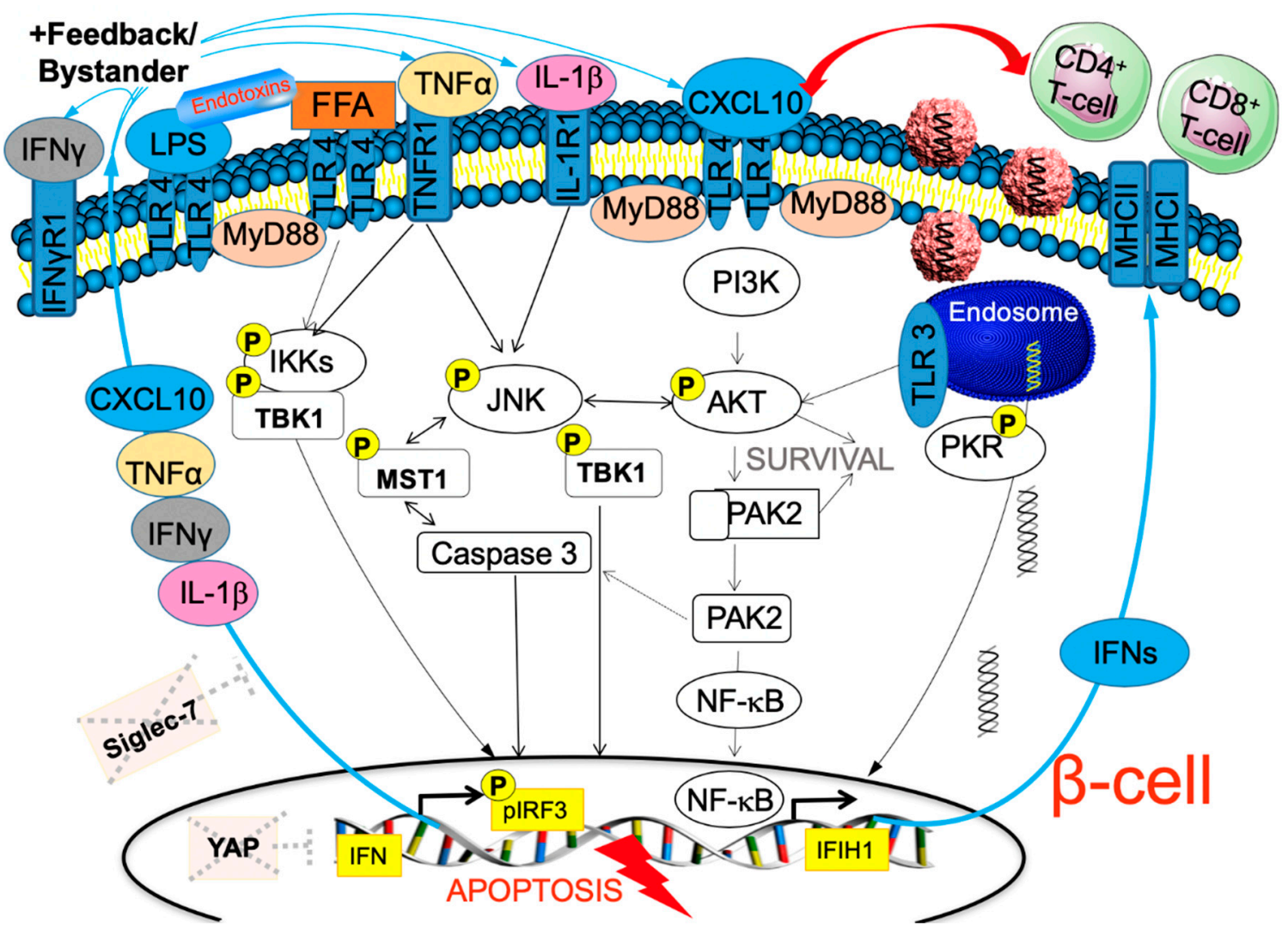

Figure 4. $\beta$-cell in the storm. Our hypothetical model on how chronic potentiation of proinflammatory pathways leads to $\beta$-cell destruction. Coxsackieviruses enter the $\beta$-cell through the Coxsackie-adenovirus receptor (CAR) and bind to endosomal TLR3. While the virus promotes the AKT-JNK axis for initial host cell survival, parallel activation of viral response pathways through PKR-TBK-IRF3 leads to the transcriptional activation of the IFN response and production of interferons, which increase surface MHCs, recognized by cytotoxic CD8- and CD4-T-cells causing "bystander damage", and $\beta$-cell apoptosis through a "storm" of cytokines and chemokines, which all find their receptors on the surface of the $\beta$-cell, and a vicious cycle is initiated with the full activation of the apoptotic machinery including JNK-MST1-Caspase 3-NFKB. Bacterial toxins as well as chronically elevated free fatty acids (FFA) are also associated with $\beta$-cell damage and act through TLR4 activation and similar downstream pro-inflammatory pathways. While many cells can counteract such damage cycles with a potent survival machinery, the $\beta$-cell is deficient of the Hippo terminator YAP, which would balance the viral IRF3 response. Furthermore, Siglec-7, which balances immune activation, is diminished in a chronic diabetogenic pro-inflammatory milieu in the $\beta$-cell.

\section{Enteroviral Infection and T1D: Results from the TEDDY Study}

Recent results from the large multi-center TEDDY cohort study provided important confirmation of the association of enteroviral infection and islet autoimmunity [96]. Direct next-generation sequencing of stool samples as well as analyses subsequent to cell culture amplification of enteroviruses identified an array of DNA and RNA viruses.

The study confirmed that enterovirus B infections (EVB) were associated with islet autoimmunity, but also examined the role of length of infection since sequential stools from children were available. An association with islet autoimmunity was detected with long-duration enterovirus B infections, indicated by prolonged shedding of the same virus in multiple stool samples. In contrast, multiple independent short-term enterovirus B infections without prolonged shedding neither correlated with autoimmunity nor with T1D progression. 
The results of this study indeed reproduce a correlation of enteroviral infection and autoimmunity: that the duration of the virus load detectable in stool samples determines the progression to autoimmunity. Mechanistically, one can assume from this and many previous studies that the virus may trigger autoimmunity, but is not conclusively linked to further T1D progression.

This is in line with data showing that the enteroviral signaling cascade, which leads to the IFN response, is increased before auto-antibody conversion and T1D (see above) [97], which again suggests virus infection and the boosted IFN response as primary event toward autoimmunity. It is very likely that the longer duration of enterovirus abidance in the host is defined by the genes and their unfavorable seasonal changes.

Once a host is found, the virus creates a variety of smart mechanisms to escape from anti-viral immune response through persistent infection, e.g., blocking autophagy in order to remain in the cell [16]. Dysfunctional autophagy as a feature of both T1D and T2D [98] supports such hypothesis. Enteroviral B's typical 5' terminal genomic deletions observed in cardiomyocytes [99] and in the pancreas [76] may lead to a long term stay of viruses in the cell without causing lysis. This probably enables detection of viral RNA in autopsy pancreata even a long time after occurrence of islet auto-antibodies [80] as well as after T1D diagnosis [77] in morphologically normal appearing cells.

Highly sensitive virus-captured sequencing methods from stool samples also confirm the association of enteroviral infection with islet autoimmunity [72], and enteroviral amplification-enrichment cultures of leukocytes and of cells from duodenal biopsies showed the correlation of enteroviruses B and T1D. A significant association between enterovirus and subsequent risk of autoimmunity in celiac disease was also found in TEDDY and other previous studies [57,100], where enteroviral positive stool samples correlated with celiac disease only after introduction of gluten to the babies' diet [57], and higher amounts of gluten consumption potentiated the effect of enteroviruses on the risk of coeliac disease autoimmunity [100], indicating the necessity of the initial autoimmunity trigger.

\section{TLR3 Signaling Leads to Enterovirus-Induced $\beta$-Cell Destruction}

The innate immune response to virus infection initiates as a fingerprint with the sensing of viral pathogen-associated molecular patterns (PAMP). Such recognition is mediated by the activation of host's pattern recognition receptors (PRR) such as Toll-like receptors (TLR) on the surface of cellular membranes and cytosolic receptors including RIG-like receptors (RLR), nucleotide-binding domain-leucine-rich repeat-containing molecules (NLR) and RNA-activated protein kinase R (PKR) [101]. Many studies show that the onset of diabetes is triggered through PRRs [102-104], and PRRs have been identified as susceptibility factors for diabetes progression in genetic studies [105-107]. Most of the today's described 10 human TLRs, namely TLR2-4 and 6-9 have been associated with T1D or/and T2D [108,109]. There is a strong correlation of the most TLR3 polymorphisms with T1D in several $[107,110]$ but not in all studies [111].

TLRs are used by the immune system for pathogen clearance. The endosomal receptor TLR3, found not only in immune but also various non-immune cells such as the $\beta$-cell, is one of the signaling complexes implicated in viral-mediated $\beta$-cell death, is highly expressed in the pancreas of patients with T1D [112] and is found enhanced in human islets by IFN exposure [113]. Once viral RNA is recognized by TLR3, the TLR3-TANK binding kinase 1 (TBK1)-IFN-regulatory factor (IRF)3/7 signaling axis is activated [114]; the virus initially induces AKT [60] to make sure that its host survives but later cross-talks with JNK result in activation and translocation of NF-kB subunits to the nucleus (Figure 4).

Downstream of the viral response pathway is the C-X-C motif chemokine 10 (CXCL10) which promotes human $\beta$-cell apoptosis [94]. CXCL10 is localized in infected islets [115] in both canonical and fulminant T1D early in disease progression [44,94] and thus is suggested as a clinical marker for diabetes onset [116]. The cascade finally ends in the secretion of proinflammatory chemokines and cytokines, which further potentiate inflammation and $\beta$-cell apoptosis pathways (Figure 4).

Several studies in mice have shown that TLR3 is an essential element of T1D development in response to viral infection. As a detector of viral signatures, TLR3 is needed for the anti-viral 
response, and, naturally, will promote cytokine signaling. These two apparent conflicting effects towards beta-cell survival may provide reasons for various different results in mice and imply that a highly balanced physiological function of viral sensors is necessary to prevent damage to $\beta$-cells. TLR3 signals contribute to the host's survival, as CVB4 [117] or encephalomyocarditis virus [118] infections are highly mortal to TLR3 knockout mice due to the impaired antiviral response machinery. Although they present a reduced pro-inflammatory milieu, surviving mice develop T1D [117]. Other studies show that TLR3 knockout in NOD mice has no effect on the incidence of diabetes at a basal level [119] and that CVB4-infected TLR3 knockout NOD mice show lower diabetes incidence [120]. In the absence of TRIF, a prominent downstream protein in the TLR3 cascade, mice are also protected from the development of T1D by changing the gut microbiota [121].

In summary, pattern recognition receptors identify viral antigens to trigger the host defense. TLR3 signaling through multiple loops leads to virus-mediated inflammatory response, and ongoing inflammation further potentiates the cytokine response through multiple cytokine and chemokine receptors expressed in the $\beta$-cell, and finally to $\beta$-cell apoptosis in vitro. However, as many examples show, mutations in a single PRR, e.g., TLR3, or its activation alone will not ultimately cause T1D, but may rather act within a pro-inflammatory network to potentiate T1D progression (Figure 4). A future research target towards prevention could therefore be specific miRNAs, as many of them which are differentially expressed in T1D patients [122] are involved in the regulation of the innate as well as the adaptive immunity through TLR signaling [123].

\section{IFN-Inducible Genes Link Autoimmunity, Viral Response and $\beta$-Cell Failure in T1D}

T1D is associated with over 60 genetic risk regions across the human genome, identified by genome-wide association studies (GWAS) [124], and these T1D-linked SNPs alter the expression of over 200 genes [125] involved in $\beta$-cell inflammation, function and destruction, immune activation and signaling, including viral response, Toll-like receptor, cytokines and NF- $\mathrm{kB}$ signaling. Among them, several risks as well as protective single nucleotide polymorphisms within the interferon-induced helicase-1 (IFIH1) gene, which encodes the melanoma differentiation associated protein 5 (MDA5), have been identified in large studies [106,126]. IFIH1 is a cytosolic sensor of single strand viral RNA from the picornavirus family. It facilitates the interferon (IFN) response and activates the immune cells towards viral response downstream of TLR signaling. Importantly, expression of the IFN signature genes as well as the type 1 IFN response is increased in children before the T1D-associated auto-antibody conversion $[97,127]$, which suggests a primary role of IFN signals in the activation of autoimmunity and the potentiation of $\beta$-cell destruction. In $\beta$-cells, IFN signaling leads to HLA class I hyperexpression, which is a well-studied path for T1D initiation [106,128]. IFIH1 is ultimately associated with signals from enteroviruses; its mRNA expression is increased by CVB3 and CVB4 infection in human islets [114] and by synthetic double-stranded RNA Poly(I:C) in INS-1E $\beta$-cells [129], while IFIH1 silencing potently lowers the chemokine response in $\beta$-cells [129]. Foremost, a diabetes-associated IFIH1 polymorphism upregulates the IFN signature in human pancreatic islets in response to Coxsackievirus infection [130].

The upregulation of IFN-inducible genes, including IFIH1 in genetically predisposed children, was also associated with previous upper respiratory tract infections and with increased monocytic expression of the sialic-acid binding immunoglobulin-like-lectin Siglec-1 [97]. Through the recognition of specific glycans on the cell surface, Siglecs promote cellular interactions within the immune system and with sialylated pathogens; they are important regulators of the innate and adaptive immune systems and serve as checkpoints for immune regulation and autoimmunity [131]. Through their immunoreceptor tyrosine-based inhibitory motifs (ITIMs), Siglecs balance the immune response [132]. Several members of the Siglec family do not only play a role in immune-cell-pathogen interactions, but also on the level of the $\beta$-cells regulate the inflammatory response. Siglec-7 is down-regulated in both $\beta$-cells in the pancreas from patients with T1D and T2D as well as in activated immune cells. Overexpression of Siglec-7 in diabetic islets balances the immune response by reducing cytokine production and monocyte migration, which both facilitate $\beta$-cell survival and function [133]. 
The evolving field of Siglecs provides a further target to modulate the excess inflammatory/IFN response as a major facilitator for autoimmunity and $\beta$-cell failure.

\section{Why the Beta-Cell? Absence of the HIPPO Effector YAP to Balance Viral Response}

Despite certain viral tropisms, viral receptors are distributed in many cells in all organs and IFN-induced viral defense mechanisms are in place, which (i) hinder viral reproduction and (ii) attract cytotoxic T-cells. In the largely non-replicative $\beta$-cells, such an increase in the IFN response seems deleterious. The intracellular antiviral defence is initiated by TBK1-IRF3-mediated interferon production (see Sections 6 and 7 above) [134] and controlled by the Hippo terminators and transcriptional regulators YAP and TAZ [135-137], which negatively regulate and thus balance the antiviral immune response. Recent studies have linked YAP/TAZ with antiviral sensing [135-137]. YAP/TAZ associate with both TBK1 and the inhibitor of nuclear factor kappa-B kinase (IKKE), thereby blocking their activation and subsequently inhibiting IRF3-stimulated transcription of viral response genes. Thus, YAP/TAZ, besides their well-known function in the regulation of cellular contact, development, growth and proliferation as effectors of the Hippo pathway [138], can regulate the host's cellular response. In the absence of this YAP regulation, virus sensing would trigger an extremely high and uncoordinated cytokine response, as happens in T1D, where virus-infected $\beta$-cells show highly increased cytokine production resulting in a vicious cycle and bystander damage of $\beta$-cells through their cytokine receptors (Figure 4).

One underlying reason could be the absence of YAP in adult $\beta$-cells. During endocrine cell differentiation, YAP is suppressed as soon as Ngn3 is expressed $[139,140]$. The lack of YAP expression correlates with the extremely low rate of $\beta$-cell proliferation and $\beta$-cell quiescence after birth and their limited regenerative capability [141]. The Hippo element YAP is sufficient to wake $\beta$-cells up from quiescence; re-expression of constitutively active YAP leads to a robust induction of human $\beta$-cell proliferation $[140,142]$. Similarly, TAZ is extremely low but detectable in both adult human and mouse $\beta$ - and $\alpha$-cells $[143,144]$. Bioinformatic analysis identified YAP as a selectively repressed ("disallowed") gene in the pancreatic islet [145]; it is more repressed in purified mouse $\beta$-cells compared to $\alpha$-cells [146]. Now, we hypothesize this as the reason not only for the much lower proliferative capacity of $\beta$-cells compared to any other endocrine cell type, but also for the extreme and suicidal viral response. In contrast, the Hippo kinase MST1 represses antiviral signaling and acts as negative regulator of the antiviral defense by its direct interaction and phosphorylation of IRF3 and inhibition of TBK1 [137]; however, underlying mechanisms as well as consequences on host survival are not known. Previous data from our and other labs show that Hippo is an important regulator of $\beta$-cell function and survival $[139,140,147]$, and therefore it may also be involved in the pathological viral response associated with T1D.

\section{Conclusions}

There is large evidence for enteroviral infection initiating the auto-immune response and subsequent $\beta$-cell destruction in genetically predisposed individuals, where a viral response is boosted. As an especially vulnerable cell to inflammatory destruction and apoptosis, autoimmunity is directed to the $\beta$-cell, causing T1D. Although enteroviruses selectively and severely destroy $\beta$-cells in vitro, they are just one stimulating factor in the huge complexity of T1D, and thus, without an unphysiological genetic predisposition towards immune activation and $\beta$-cells' inability for compensation, they would probably not cause T1D. Therefore, it is possible that enteroviral vaccination and antiviral therapies for T1D [148], although they would take away the stimulus, may alone not be sufficient to cure the disease and require combination with further $\beta$-cell protection efficacy. This is reminiscent of gluco- and lipotoxicity-mediated $\beta$-cell failure associated with T2D [149]. Although highly toxic for the $\beta$-cell in vitro, elevated glucose and free fatty acids only induce some alterations and systemic compensation as long-term consequences of obesity in vivo. However, in genetically predisposed individuals, they finally lead to T2D [150]. Similarly, neither viral infections alone nor 
predisposing genetic polymorphisms alone ultimately lead to T1D. As there is no single cause for T1D, we will probably not be able to successfully cure diabetes with a single drug. Rather, forces need to join for testing the efficacy of combination therapies, for example antiviral strategies [148] together with the prevention of T-cell action [151], anti-inflammation [152] and/or beta-cell protection [153].

Funding: This research was funded by JDRF and by the German Research Foundation (DFG).

Acknowledgments: We would like to thank Kaarthik Sridharan, University of Bremen, for his input and help with manuscript editing. We are grateful for the continuous support from the Network for Pancreatic Organ Donors with Diabetes (nPOD), a collaborative type 1 diabetes research project sponsored by JDRF and Organ Procurement Organizations (OPO) partnering with nPOD to provide research resources (http://www.jdrfnpod. org/for-partners/npod-partners/). Without this excellent collection of well-preserved and well-characterized pancreases, lots of the studies discussed in this review would not have been possible. We further thank all members of the nPOD-Virus group headed by Alberto Pugliese, University of Miami for collaboration, discussion and support.

Conflicts of Interest: The authors declare no conflict of interest.

\section{References}

1. Jacobsen, L.M.; Newby, B.N.; Perry, D.J.; Posgai, A.L.; Haller, M.J.; Brusko, T.M. Immune mechanisms and pathways targeted in type 1 diabetes. Curr. Diabetes Rep. 2018, 18, 90. [CrossRef] [PubMed]

2. Wallberg, M.; Cooke, A. Immune mechanisms in type 1 diabetes. Trends Immunol. 2013, 34, 583-591. [CrossRef] [PubMed]

3. Pociot, F.; Lernmark, A. Genetic risk factors for type 1 diabetes. Lancet 2016, 387, 2331-2339. [CrossRef]

4. Herold, K.C.; Vignali, D.A.; Cooke, A.; Bluestone, J.A. Type 1 diabetes: Translating mechanistic observations into effective clinical outcomes. Nat. Rev. Immunol. 2013, 13, 243-256. [CrossRef] [PubMed]

5. Hyoty, H.; Taylor, K.W. The role of viruses in human diabetes. Diabetologia 2002, 45, 1353-1361. [CrossRef] [PubMed]

6. Yeung, W.C.; Rawlinson, W.D.; Craig, M.E. Enterovirus infection and type 1 diabetes mellitus: Systematic review and meta-analysis of observational molecular studies. BMJ 2011, 342, d35. [CrossRef]

7. Oikarinen, M.; Tauriainen, S.; Oikarinen, S.; Honkanen, T.; Collin, P.; Rantala, I.; Maki, M.; Kaukinen, K.; Hyoty, H. Type 1 diabetes is associated with enterovirus infection in gut mucosa. Diabetes 2012, 61, 687-691. [CrossRef]

8. Kyvik, K.O.; Green, A.; Beck-Nielsen, H. Concordance rates of insulin dependent diabetes mellitus: A population based study of young Danish twins. BMJ 1995, 311, 913-917. [CrossRef]

9. Adams, S.F. The seasonal variation in the onset of acute diabetes: The age and sex factor in 1,000 diabetic patients. Arch. Intern. Med. 1926, 37, 3861. [CrossRef]

10. Morgan, N.G.; Richardson, S.J. Enteroviruses as causative agents in type 1 diabetes: Loose ends or lost cause? Trends Endocrinol. Metab. 2014, 25, 611-619. [CrossRef]

11. Hober, D.; Alidjinou, E.K. Enteroviral pathogenesis of type 1 diabetes: Queries and answers. Curr. Opin. Infect. Dis. 2013, 26, 263-269. [CrossRef] [PubMed]

12. Hober, D.; Sane, F. Enteroviral pathogenesis of type 1 diabetes. Discov. Med. 2010, 10, 151-160. [CrossRef]

13. Vabret, N.; Britton, G.J.; Gruber, C.; Hegde, S.; Kim, J.; Kuksin, M.; Levantovsky, R.; Malle, L.; Moreira, A.; Park, M.D.; et al. Immunology of COVID-19: Current state of the science. Immunity 2020, 52, 910-941. [CrossRef] [PubMed]

14. Rubino, F.; Amiel, S.A.; Zimmet, P.; Alberti, G.; Bornstein, S.; Eckel, R.H.; Mingrone, G.; Boehm, B.; Cooper, M.E.; Chai, Z.; et al. New-onset diabetes in Covid-19. N. Engl. J. Med. 2020. [CrossRef]

15. Chee, Y.J.; Ng, S.J.H.; Yeoh, E. Diabetic ketoacidosis precipitated by Covid-19 in a patient with newly diagnosed diabetes mellitus. Diabetes Res. Clin. Pract. 2020, 164, 108166. [CrossRef] [PubMed]

16. Sin, J.; Mangale, V.; Thienphrapa, W.; Gottlieb, R.A.; Feuer, R. Recent progress in understanding coxsackievirus replication, dissemination, and pathogenesis. Virology 2015, 484, 288-304. [CrossRef] [PubMed]

17. Martinez, M.E. The calendar of epidemics: Seasonal cycles of infectious diseases. PLoS Pathog. 2018, 14, e1007327. [CrossRef]

18. Lee, C.J.; Huang, Y.C.; Yang, S.; Tsao, K.C.; Chen, C.J.; Hsieh, Y.C.; Chiu, C.H.; Lin, T.Y. Clinical features of coxsackievirus A4, B3 and B4 infections in children. PLoS ONE 2014, 9, e87391. [CrossRef] 
19. Watad, A.; Azrielant, S.; Bragazzi, N.L.; Sharif, K.; David, P.; Katz, I.; Aljadeff, G.; Quaresma, M.; Tanay, G.; Adawi, M.; et al. Seasonality and autoimmune diseases: The contribution of the four seasons to the mosaic of autoimmunity. J. Autoimmun. 2017, 82, 13-30. [CrossRef]

20. Moltchanova, E.V.; Schreier, N.; Lammi, N.; Karvonen, M. Seasonal variation of diagnosis of type 1 diabetes mellitus in children worldwide. Diabet. Med. 2009, 26, 673-678. [CrossRef]

21. Szypowska, A.; Ramotowska, A.; Wysocka-Mincewicz, M.; Mazur, A.; Lisowicz, L.; Ben-Skowronek, I.; Sieniawska, J.; Klonowska, B.; Charemska, D.; Nawrotek, J.; et al. Seasonal variation in month of diagnosis of polish children with type 1 diabetes - A Multicenter Study. Exp. Clin. Endocrinol. Diabetes 2019, 127, 331-335. [CrossRef] [PubMed]

22. Spaans, E.A.; van Dijk, P.R.; Groenier, K.H.; Brand, P.L.; Reeser, M.H.; Bilo, H.J.; Kleefstra, N. Seasonality of diagnosis of type 1 diabetes mellitus in the Netherlands (Young Dudes-2). J. Pediatr. Endocrinol. Metab. 2016, 29, 657-661. [CrossRef] [PubMed]

23. Patterson, C.C.; Karuranga, S.; Salpea, P.; Saeedi, P.; Dahlquist, G.; Soltesz, G.; Ogle, G.D. Worldwide estimates of incidence, prevalence and mortality of type 1 diabetes in children and adolescents: Results from the International Diabetes Federation diabetes atlas, 9th edition. Diabetes Res. Clin. Pract. 2019, 157, 107842. [CrossRef] [PubMed]

24. Kimpimaki, T.; Kupila, A.; Hamalainen, A.M.; Kukko, M.; Kulmala, P.; Savola, K.; Simell, T.; Keskinen, P.; Ilonen, J.; Simell, O.; et al. The first signs of beta-cell autoimmunity appear in infancy in genetically susceptible children from the general population: The finnish type 1 diabetes prediction and prevention study. J. Clin. Endocrinol. Metab. 2001, 86, 4782-4788. [CrossRef]

25. Kahaly, G.J.; Hansen, M.P. Type 1 diabetes associated autoimmunity. Autoimmun. Rev. 2016, 15, 644-648. [CrossRef]

26. Lonnrot, M.; Korpela, K.; Knip, M.; Ilonen, J.; Simell, O.; Korhonen, S.; Savola, K.; Muona, P.; Simell, T.; Koskela, P.; et al. Enterovirus infection as a risk factor for beta-cell autoimmunity in a prospectively observed birth cohort: The finnish diabetes prediction and prevention study. Diabetes 2000, 49, 1314-1318. [CrossRef]

27. Hiltunen, M.; Hyoty, H.; Knip, M.; Ilonen, J.; Reijonen, H.; Vahasalo, P.; Roivainen, M.; Lonnrot, M.; Leinikki, P.; Hovi, T.; et al. Islet cell antibody seroconversion in children is temporally associated with enterovirus infections. Childhood Diabetes in Finland (DiMe) Study Group. J. Infect. Dis. 1997, 175, 554-560. [CrossRef]

28. Hyoty, H.; Hiltunen, M.; Knip, M.; Laakkonen, M.; Vahasalo, P.; Karjalainen, J.; Koskela, P.; Roivainen, M.; Leinikki, P.; Hovi, T.; et al. A prospective study of the role of coxsackie B and other enterovirus infections in the pathogenesis of IDDM. Childhood Diabetes in Finland (DiMe) Study Group. Diabetes 1995, 44, 652-657. [CrossRef]

29. Sioofy-Khojine, A.B.; Lehtonen, J.; Nurminen, N.; Laitinen, O.H.; Oikarinen, S.; Huhtala, H.; Pakkanen, O.; Ruokoranta, T.; Hankaniemi, M.M.; Toppari, J.; et al. Coxsackievirus B1 infections are associated with the initiation of insulin-driven autoimmunity that progresses to type 1 diabetes. Diabetologia 2018, 61, 1193-1202. [CrossRef]

30. Graves, P.M.; Rotbart, H.A.; Nix, W.A.; Pallansch, M.A.; Erlich, H.A.; Norris, J.M.; Hoffman, M.; Eisenbarth, G.S.; Rewers, M. Prospective study of enteroviral infections and development of beta-cell autoimmunity. diabetes autoimmunity study in the young (DAISY). Diabetes Res. Clin. Pract. 2003, 59, 51-61. [CrossRef]

31. Fuchtenbusch, M.; Irnstetter, A.; Jager, G.; Ziegler, A.G. No evidence for an association of coxsackie virus infections during pregnancy and early childhood with development of islet autoantibodies in offspring of mothers or fathers with type 1 diabetes. J. Autoimmun. 2001, 17, 333-340. [CrossRef] [PubMed]

32. Mathieu, C. Vitamin D and diabetes: Where do we stand? Diabetes Res. Clin. Pract. 2015, 108, $201-209$. [CrossRef] [PubMed]

33. Infante, M.; Ricordi, C.; Sanchez, J.; Clare-Salzler, M.J.; Padilla, N.; Fuenmayor, V.; Chavez, C.; Alvarez, A.; Baidal, D.; Alejandro, R.; et al. Influence of vitamin D on islet autoimmunity and beta-cell function in type 1 diabetes. Nutrients 2019, 11, 2185. [CrossRef] [PubMed]

34. Dopico, X.C.; Evangelou, M.; Ferreira, R.C.; Guo, H.; Pekalski, M.L.; Smyth, D.J.; Cooper, N.; Burren, O.S.; Fulford, A.J.; Hennig, B.J.; et al. Widespread seasonal gene expression reveals annual differences in human immunity and physiology. Nat. Commun. 2015, 6, 7000. [CrossRef] [PubMed] 
35. Lebailly, B.; Boitard, C.; Rogner, U.C. Circadian rhythm-related genes: Implication in autoimmunity and type 1 diabetes. Diabetes Obes. Metab. 2015, 17 (Suppl. 1), 134-138. [CrossRef]

36. Marcheva, B.; Ramsey, K.M.; Buhr, E.D.; Kobayashi, Y.; Su, H.; Ko, C.H.; Ivanova, G.; Omura, C.; Mo, S.; Vitaterna, M.H.; et al. Disruption of the clock components CLOCK and BMAL1 leads to hypoinsulinaemia and diabetes. Nature 2010, 466, 627-631. [CrossRef]

37. Javeed, N.; Brown, M.R.; Rakshit, K.; Her, T.; Sen, S.K.; Matveyenko, A.V. Pro-inflammatory cytokine interleukin 1 beta disrupts beta cell circadian clock function and regulation of insulin secretion. Endocrinology 2020. [CrossRef]

38. Wu, Y.; Tang, D.; Liu, N.; Xiong, W.; Huang, H.; Li, Y.; Ma, Z.; Zhao, H.; Chen, P.; Qi, X.; et al. Reciprocal Regulation between the circadian clock and hypoxia signaling at the genome level in mammals. Cell Metab. 2017, 25, 73-85. [CrossRef]

39. Early, J.O.; Menon, D.; Wyse, C.A.; Cervantes-Silva, M.P.; Zaslona, Z.; Carroll, R.G.; Palsson-McDermott, E.M.; Angiari, S.; Ryan, D.G.; Corcoran, S.E.; et al. Circadian clock protein BMAL1 regulates IL-1beta in macrophages via NRF2. Proc. Nat. Acad. Sci. USA 2018, 115, E8460-E8468. [CrossRef]

40. He, W.; Rebello, O.; Savino, R.; Terracciano, R.; Schuster-Klein, C.; Guardiola, B.; Maedler, K. TLR4 triggered complex inflammation in human pancreatic islets. Biochim. Biophys. Acta. Mol. Basis Dis. 2019, 1865, 86-97. [CrossRef]

41. He, W.; Yuan, T.; Maedler, K. Macrophage-associated pro-inflammatory state in human islets from obese individuals. Nutr. Diabetes 2019, 9, 36. [CrossRef] [PubMed]

42. Peek, C.B.; Levine, D.C.; Cedernaes, J.; Taguchi, A.; Kobayashi, Y.; Tsai, S.J.; Bonar, N.A.; McNulty, M.R.; Ramsey, K.M.; Bass, J. Circadian clock interaction with HIF1alpha mediates oxygenic metabolism and anaerobic glycolysis in skeletal muscle. Cell Metab. 2017, 25, 86-92. [CrossRef] [PubMed]

43. Schurman, S.H.; O'Hanlon, T.P.; McGrath, J.A.; Gruzdev, A.; Bektas, A.; Xu, H.; Garantziotis, S.; Zeldin, D.C.; Miller, F.W. Transethnic associations among immune-mediated diseases and single-nucleotide polymorphisms of the aryl hydrocarbon response gene ARNT and the PTPN22 immune regulatory gene. J. Autoimmun. 2020, 107, 102363. [CrossRef] [PubMed]

44. Paroni, F.; Domsgen, E.; Maedler, K. CXCL10- a path to beta-cell death. Islets 2009, 1, 256-259. [CrossRef]

45. Al Badri, A.M.; Foulis, A.K.; Todd, P.M.; Gariouch, J.J.; Gudgeon, J.E.; Stewart, D.G.; Gracie, J.A.; Goudie, R.B. Abnormal expression of MHC class II and ICAM-1 by melanocytes in vitiligo. J. Pathol. 1993, 169, $203-206$. [CrossRef]

46. Noble, J.A. Immunogenetics of type 1 diabetes: A comprehensive review. J. Autoimmun. 2015, 64, 101-112. [CrossRef]

47. Valdes, A.M.; Erlich, H.A.; Noble, J.A. Human leukocyte antigen class I B and C loci contribute to type 1 diabetes (T1D) susceptibility and age at T1D onset. Hum. Immunol. 2005, 66, 301-313. [CrossRef]

48. Nejentsev, S.; Howson, J.M.; Walker, N.M.; Szeszko, J.; Field, S.F.; Stevens, H.E.; Reynolds, P.; Hardy, M.; King, E.; Masters, J.; et al. Localization of type 1 diabetes susceptibility to the MHC class I genes HLA-B and HLA-A. Nature 2007, 450, 887-892. [CrossRef]

49. Valdes, A.M.; Erlich, H.A.; Carlson, J.; Varney, M.; Moonsamy, P.V.; Noble, J.A. Use of class I and class II HLA loci for predicting age at onset of type 1 diabetes in multiple populations. Diabetologia 2012, 55, 2394-2401. [CrossRef]

50. Hietala, K.; Harjutsalo, V.; Forsblom, C.; Summanen, P.; Groop, P.H.; FinnDiane Study, G. Age at onset and the risk of proliferative retinopathy in type 1 diabetes. Diabetes Care 2010, 33, 1315-1319. [CrossRef]

51. Hoffmann, V.S.; Weiss, A.; Winkler, C.; Knopff, A.; Jolink, M.; Bonifacio, E.; Ziegler, A.G. Landmark models to define the age-adjusted risk of developing stage 1 type 1 diabetes across childhood and adolescence. BMC Med. 2019, 17, 125. [CrossRef] [PubMed]

52. Rodriguez-Calvo, T.; Richardson, S.J.; Pugliese, A. pancreas pathology during the natural history of type 1 diabetes. Curr. Diabetes Rep. 2018, 18, 124. [CrossRef]

53. Richardson, S.J.; Rodriguez-Calvo, T.; Gerling, I.C.; Mathews, C.E.; Kaddis, J.S.; Russell, M.A.; Zeissler, M.; Leete, P.; Krogvold, L.; Dahl-Jorgensen, K.; et al. Islet cell hyperexpression of HLA class I antigens: A defining feature in type 1 diabetes. Diabetologia 2016, 59, 2448-2458. [CrossRef] [PubMed]

54. Chehadeh, W.; Kerr-Conte, J.; Pattou, F.; Alm, G.; Lefebvre, J.; Wattre, P.; Hober, D. Persistent infection of human pancreatic islets by coxsackievirus B is associated with alpha interferon synthesis in beta cells. J. Virol. 2000, 74, 10153-10164. [CrossRef] 
55. Vives-Pi, M.; Armengol, M.P.; Alcalde, L.; Costa, M.; Somoza, N.; Vargas, F.; Jaraquemada, D.; Pujol-Borrell, R. Expression of transporter associated with antigen processing- 1 in the endocrine cells of human pancreatic islets: Effect of cytokines and evidence of hyperexpression in IDDM. Diabetes 1996, 45, 779-788. [CrossRef] [PubMed]

56. Marroqui, L.; Dos Santos, R.S.; Op de Beeck, A.; Coomans de Brachene, A.; Marselli, L.; Marchetti, P.; Eizirik, D.L. Interferon-alpha mediates human beta cell HLA class I overexpression, endoplasmic reticulum stress and apoptosis, three hallmarks of early human type 1 diabetes. Diabetologia 2017, 60, 656-667. [CrossRef] [PubMed]

57. Kahrs, C.R.; Chuda, K.; Tapia, G.; Stene, L.C.; Marild, K.; Rasmussen, T.; Ronningen, K.S.; Lundin, K.E.A.; Kramna, L.; Cinek, O.; et al. Enterovirus as trigger of coeliac disease: Nested case-control study within prospective birth cohort. BMJ 2019, 364, 1231. [CrossRef] [PubMed]

58. Beyerlein, A.; Donnachie, E.; Jergens, S.; Ziegler, A.G. Infections in early life and development of type 1 diabetes. Jama 2016, 315, 1899-1901. [CrossRef]

59. Gamble, D.R.; Kinsley, M.L.; FitzGerald, M.G.; Bolton, R.; Taylor, K.W. Viral antibodies in diabetes mellitus. Br. Med. J. 1969, 3, 627-630. [CrossRef]

60. Domsgen, E.; Paroni, F.; Kerr-Conte, J.; Dotzauer, A.; Maedler, K. Virus-induced beta cell death depends on CXCL10 and the AKT-JNK-PKR crosstalk. Diabetologia 2010, 53, S186.

61. Christen, U.; von Herrath, M.G. Do viral infections protect from or enhance type 1 diabetes and how can we tell the difference? Cell Mol. Immunol. 2011, 8, 193-198. [CrossRef]

62. Rodriguez-Calvo, T.; von Herrath, M.G. Enterovirus infection and type 1 diabetes: Closing in on a link? Diabetes 2015, 64, 1503-1505. [CrossRef] [PubMed]

63. Yoon, J.W.; Austin, M.; Onodera, T.; Notkins, A.L. Isolation of a virus from the pancreas of a child with diabetic ketoacidosis. N. Engl. J. Med. 1979, 300, 1173-1179. [CrossRef] [PubMed]

64. Krogvold, L.; Edwin, B.; Buanes, T.; Frisk, G.; Skog, O.; Anagandula, M.; Korsgren, O.; Undlien, D.; Eike, M.C.; Richardson, S.J.; et al. Detection of a low-grade enteroviral infection in the islets of langerhans of living patients newly diagnosed with type 1 diabetes. Diabetes 2015, 64, 1682-1687. [CrossRef] [PubMed]

65. Skog, O.; Ingvast, S.; Korsgren, O. Evaluation of RT-PCR and immunohistochemistry as tools for detection of enterovirus in the human pancreas and islets of Langerhans. J. Clin. Virol. 2014, 61, 242-247. [CrossRef]

66. Richardson, S.J.; Leete, P.; Bone, A.J.; Foulis, A.K.; Morgan, N.G. Expression of the enteroviral capsid protein VP1 in the islet cells of patients with type 1 diabetes is associated with induction of protein kinase $\mathrm{R}$ and downregulation of Mcl-1. Diabetologia 2013, 56, 185-193. [CrossRef]

67. Oikarinen, S.; Tauriainen, S.; Hober, D.; Lucas, B.; Vazeou, A.; Sioofy-Khojine, A.; Bozas, E.; Muir, P.; Honkanen, H.; Ilonen, J.; et al. Virus antibody survey in different European populations indicates risk association between coxsackievirus B1 and type 1 diabetes. Diabetes 2014, 63, 655-662. [CrossRef]

68. Dezayee, Z.M. The status of serum gamma-interferonand antiviral antibodies in patients with type I and type 2 diabetes: A comparative study. J. Res. Med. Sci. 2012, 17, 855-858.

69. Alberti, A.M.; Amato, C.; Candela, A.; Costantino, F.; Grandolfo, M.E.; Lombardi, F.; Novello, F.; Orsini, M.; Santoro, R. Serum antibodies against Coxsackie B1-6 viruses in type 1 diabetics. Acta Diabetol. Lat. 1985, 22, 33-38. [CrossRef]

70. Oikarinen, S.; Martiskainen, M.; Tauriainen, S.; Huhtala, H.; Ilonen, J.; Veijola, R.; Simell, O.; Knip, M.; Hyoty, H. Enterovirus RNA in blood is linked to the development of type 1 diabetes. Diabetes 2011, 60, 276-279. [CrossRef]

71. Genoni, A.; Canducci, F.; Rossi, A.; Broccolo, F.; Chumakov, K.; Bono, G.; Salerno-Uriarte, J.; Salvatoni, A.; Pugliese, A.; Toniolo, A. Revealing enterovirus infection in chronic human disorders: An integrated diagnostic approach. Sci. Rep. 2017, 7, 5013. [CrossRef] [PubMed]

72. Kim, K.W.; Horton, J.L.; Pang, C.N.I.; Jain, K.; Leung, P.; Isaacs, S.R.; Bull, R.A.; Luciani, F.; Wilkins, M.R.; Catteau, J.; et al. Higher abundance of enterovirus A species in the gut of children with islet autoimmunity. Sci. Rep. 2019, 9, 1749. [CrossRef] [PubMed]

73. Yoon, J.W.; Jun, H.S. Viruses cause type 1 diabetes in animals. Ann. N. Y. Acad. Sci. 2006, 1079, $138-146$. [CrossRef] [PubMed]

74. Hober, D.; Sane, F. Enteroviruses and type 1 diabetes. BMJ 2011, 342, c7072. [CrossRef]

75. Sane, F.; Caloone, D.; Gmyr, V.; Engelmann, I.; Belaich, S.; Kerr-Conte, J.; Pattou, F.; Desailloud, R.; Hober, D. Coxsackievirus B4 can infect human pancreas ductal cells and persist in ductal-like cell cultures which results 
in inhibition of Pdx1 expression and disturbed formation of islet-like cell aggregates. Cell. Mol. Life Sci. 2013, 70, 4169-4180. [CrossRef]

76. Tracy, S.; Smithee, S.; Alhazmi, A.; Chapman, N. Coxsackievirus can persist in murine pancreas by deletion of $5^{\prime}$ terminal genomic sequences. J. Med. Virol. 2015, 87, 240-247. [CrossRef]

77. Busse, N.; Paroni, F.; Richardson, S.J.; Laiho, J.E.; Oikarinen, M.; Frisk, G.; Hyoty, H.; de Koning, E.; Morgan, N.G.; Maedler, K. Detection and localization of viral infection in the pancreas of patients with type 1 diabetes using short fluorescently-labelled oligonucleotide probes. Oncotarget 2017, 8, 12620-12636. [CrossRef]

78. Laiho, J.E.; Oikarinen, S.; Oikarinen, M.; Larsson, P.G.; Stone, V.M.; Hober, D.; Oberste, S.; Flodstrom-Tullberg, M.; Isola, J.; Hyoty, H. Application of bioinformatics in probe design enables detection of enteroviruses on different taxonomic levels by advanced in situ hybridization technology. J. Clin. Virol. 2015, 69, 165-171. [CrossRef]

79. Laiho, J.E.; Oikarinen, M.; Richardson, S.J.; Frisk, G.; Nyalwidhe, J.; Burch, T.C.; Morris, M.A.; Oikarinen, S.; Pugliese, A.; Dotta, F; et al. Relative sensitivity of immunohistochemistry, multiple reaction monitoring mass spectrometry, in situ hybridization and PCR to detect Coxsackievirus B1 in A549 cells. J. Clin. Virol. 2016, 77, 21-28. [CrossRef]

80. Geravandi, S.; Maedler, K. Enteroviral mRNA detection in the pancreas of patients with type 1 diabetes. Diabetol. 2019, 62, S7.

81. Richardson, S.J.; Willcox, A.; Bone, A.J.; Foulis, A.K.; Morgan, N.G. The prevalence of enteroviral capsid protein vp1 immunostaining in pancreatic islets in human type 1 diabetes. Diabetologia 2009, 52, 1143-1151. [CrossRef]

82. Battaglia, M.; Atkinson, M.A. The streetlight effect in type 1 diabetes. Diabetes 2015, 64, 1081-1090. [CrossRef] [PubMed]

83. Richardson, S.J.; Leete, P.; Dhayal, S.; Russell, M.A.; Oikarinen, M.; Laiho, J.E.; Svedin, E.; Lind, K.; Rosenling, T.; Chapman, N.; et al. Evaluation of the fidelity of immunolabelling obtained with clone 5D8/1, a monoclonal antibody directed against the enteroviral capsid protein, VP1, in human pancreas. Diabetologia 2014, 57, 392-401. [CrossRef]

84. Hansson, S.F.; Korsgren, S.; Ponten, F.; Korsgren, O. Enteroviruses and the pathogenesis of type 1 diabetes revisited: Cross-reactivity of enterovirus capsid protein (VP1) antibodies with human mitochondrial proteins. J. Pathol. 2013, 229, 719-728. [CrossRef] [PubMed]

85. Mena, I.; Fischer, C.; Gebhard, J.R.; Perry, C.M.; Harkins, S.; Whitton, J.L. Coxsackievirus infection of the pancreas: Evaluation of receptor expression, pathogenesis, and immunopathology. Virology 2000, 271, 276-288. [CrossRef] [PubMed]

86. Wright, J.J.; Saunders, D.C.; Dai, C.; Poffenberger, G.; Cairns, B.; Serreze, D.V.; Harlan, D.M.; Bottino, R.; Brissova, M.; Powers, A.C. Decreased pancreatic acinar cell number in type 1 diabetes. Diabetologia 2020. [CrossRef] [PubMed]

87. Campbell-Thompson, M.L.; Filipp, S.L.; Grajo, J.R.; Nambam, B.; Beegle, R.; Middlebrooks, E.H.; Gurka, M.J.; Atkinson, M.A.; Schatz, D.A.; Haller, M.J. Relative pancreas volume is reduced in first-degree relatives of patients with type 1 diabetes. Diabetes Care 2019, 42, 281-287. [CrossRef]

88. Campbell-Thompson, M.L.; Kaddis, J.S.; Wasserfall, C.; Haller, M.J.; Pugliese, A.; Schatz, D.A.; Shuster, J.J.; Atkinson, M.A. The influence of type 1 diabetes on pancreatic weight. Diabetologia 2016, 59, $217-221$. [CrossRef]

89. Horwitz, M.S.; Bradley, L.M.; Harbertson, J.; Krahl, T.; Lee, J.; Sarvetnick, N. Diabetes induced by Coxsackie virus: Initiation by bystander damage and not molecular mimicry. Nat. Med. 1998, 4, 781-785. [CrossRef]

90. Sane, F.; Moumna, I.; Hober, D. Group B coxsackieviruses and autoimmunity: Focus on type 1 diabetes. Expert Rev. Clin. Immunol. 2011, 7, 357-366. [CrossRef]

91. Zarozinski, C.C.; Welsh, R.M. Minimal bystander activation of CD8 T cells during the virus-induced polyclonal T cell response. J. Exp. Med. 1997, 185, 1629-1639. [CrossRef] [PubMed] 
92. Seewaldt, S.; Thomas, H.E.; Ejrnaes, M.; Christen, U.; Wolfe, T.; Rodrigo, E.; Coon, B.; Michelsen, B.; Kay, T.W.; von Herrath, M.G. Virus-induced autoimmune diabetes: Most beta-cells die through inflammatory cytokines and not perforin from autoreactive (anti-viral) cytotoxic T-lymphocytes. Diabetes 2000, 49, 1801-1809. [CrossRef] [PubMed]

93. Bogdani, M.; Korpos, E.; Simeonovic, C.J.; Parish, C.R.; Sorokin, L.; Wight, T.N. Extracellular matrix components in the pathogenesis of type 1 diabetes. Curr. Diabetes Rep. 2014, 14, 552. [CrossRef] [PubMed]

94. Schulthess, F.T.; Paroni, F.; Sauter, N.S.; Shu, L.; Ribaux, P.; Haataja, L.; Strieter, R.M.; Oberholzer, J.; King, C.C.; Maedler, K. CXCL10 impairs beta cell function and viability in diabetes through TLR4 signaling. Cell Metab. 2009, 9, 125-139. [CrossRef]

95. Domsgen, E.; Paroni, F.; Kerr-Conte, J.; Dotzauer, A.; Maedler, K. Coxsackievirus initiates strong immune response and death of beta cells. Diabetologia 2012, 55, S196-S197.

96. Vehik, K.; Lynch, K.F.; Wong, M.C.; Tian, X.; Ross, M.C.; Gibbs, R.A.; Ajami, N.J.; Petrosino, J.F.; Rewers, M.; Toppari, J.; et al. Prospective virome analyses in young children at increased genetic risk for type 1 diabetes. Nat. Med. 2019, 25, 1865-1872. [CrossRef]

97. Ferreira, R.C.; Guo, H.; Coulson, R.M.; Smyth, D.J.; Pekalski, M.L.; Burren, O.S.; Cutler, A.J.; Doecke, J.D.; Flint, S.; McKinney, E.F.; et al. A type I interferon transcriptional signature precedes autoimmunity in children genetically at risk for type 1 diabetes. Diabetes 2014, 63, 2538-2550. [CrossRef]

98. Marasco, M.R.; Linnemann, A.K. Beta-cell autophagy in diabetes pathogenesis. Endocrinology 2018, 159, 2127-2141. [CrossRef]

99. Kim, K.S.; Tracy, S.; Tapprich, W.; Bailey, J.; Lee, C.K.; Kim, K.; Barry, W.H.; Chapman, N.M. 5'-Terminal deletions occur in coxsackievirus B3 during replication in murine hearts and cardiac myocyte cultures and correlate with encapsidation of negative-strand viral RNA. J. Virol. 2005, 79, 7024-7041. [CrossRef]

100. Lindfors, K.; Lin, J.; Lee, H.S.; Hyoty, H.; Nykter, M.; Kurppa, K.; Liu, E.; Koletzko, S.; Rewers, M.; Hagopian, W.; et al. Metagenomics of the faecal virome indicate a cumulative effect of enterovirus and gluten amount on the risk of coeliac disease autoimmunity in genetically at risk children: The TEDDY study. Gut 2019. [CrossRef]

101. Takeuchi, O.; Akira, S. Pattern recognition receptors and inflammation. Cell 2010, 140, 805-820. [CrossRef] [PubMed]

102. Aida, K.; Nishida, Y.; Tanaka, S.; Maruyama, T.; Shimada, A.; Awata, T.; Suzuki, M.; Shimura, H.; Takizawa, S.; Ichijo, M.; et al. RIG-I- and MDA5-initiated innate immunity linked with adaptive immunity accelerates beta-cell death in fulminant type 1 diabetes. Diabetes 2011, 60, 884-889. [CrossRef]

103. Lee, A.S.; Ghoreishi, M.; Cheng, W.K.; Chang, T.Y.; Zhang, Y.Q.; Dutz, J.P. Toll-like receptor 7 stimulation promotes autoimmune diabetes in the NOD mouse. Diabetologia 2011, 54, 1407-1416. [CrossRef] [PubMed]

104. Dasu, M.R.; Devaraj, S.; Park, S.; Jialal, I. Increased toll-like receptor (TLR) activation and TLR ligands in recently diagnosed type 2 diabetic subjects. Diabetes Care 2010, 33, 861-868. [CrossRef]

105. Smyth, D.J.; Cooper, J.D.; Bailey, R.; Field, S.; Burren, O.; Smink, L.J.; Guja, C.; Ionescu-Tirgoviste, C.; Widmer, B.; Dunger, D.B.; et al. A genome-wide association study of nonsynonymous SNPs identifies a type 1 diabetes locus in the interferon-induced helicase (IFIH1) region. Nat. Genet. 2006, 38, 617-619. [CrossRef] [PubMed]

106. Nejentsev, S.; Walker, N.; Riches, D.; Egholm, M.; Todd, J.A. Rare variants of IFIH1, a gene implicated in antiviral responses, protect against type 1 diabetes. Science 2009, 324, 387-389. [CrossRef] [PubMed]

107. Assmann, T.S.; Brondani Lde, A.; Bauer, A.C.; Canani, L.H.; Crispim, D. Polymorphisms in the TLR3 gene are associated with risk for type 1 diabetes mellitus. Eur. J. Endocrinol. 2014, 170, 519-527. [CrossRef] [PubMed]

108. Morse, Z.J.; Horwitz, M.S. Innate viral receptor signaling determines type 1 diabetes Onset. Front. Endocrinol. 2017, 8, 249. [CrossRef]

109. Tai, N.; Wong, F.S.; Wen, L. The role of the innate immune system in destruction of pancreatic beta cells in NOD mice and humans with type I diabetes. J. Autoimmun. 2016, 71, 26-34. [CrossRef]

110. Pirie, F.J.; Pegoraro, R.; Motala, A.A.; Rauff, S.; Rom, L.; Govender, T.; Esterhuizen, T.M. Toll-like receptor 3 gene polymorphisms in South African Blacks with type 1 diabetes. Tissue Antigens 2005, 66, 125-130. [CrossRef] [PubMed]

111. Fichna, M.; Zurawek, M.; Fichna, P.; Januszkiewicz-Lewandowska, D.; Ruchala, M.; Nowak, J. Polymorphisms of the toll-like receptor-3 gene in autoimmune adrenal failure and type 1 diabetes in Polish patients. Arch. Immunol. Ther. Exp. 2016, 64, 83-87. [CrossRef] [PubMed] 
112. Shibasaki, S.; Imagawa, A.; Tauriainen, S.; Iino, M.; Oikarinen, M.; Abiru, H.; Tamaki, K.; Seino, H.; Nishi, K.; Takase, I.; et al. Expression of toll-like receptors in the pancreas of recent-onset fulminant type 1 diabetes. Endocr. J. 2010, 57, 211-219. [CrossRef] [PubMed]

113. Hultcrantz, M.; Huhn, M.H.; Wolf, M.; Olsson, A.; Jacobson, S.; Williams, B.R.; Korsgren, O.; Flodstrom-Tullberg, M. Interferons induce an antiviral state in human pancreatic islet cells. Virology 2007, 367, 92-101. [CrossRef] [PubMed]

114. Domsgen, E.; Paroni, F.; Kerr-Conte, J.; Dotzauer, A.; Maedler, K. Endosomal TLR3 activation by Coxsackievirus initiates strong immune response and death of beta cells. Diabetologia 2011, 54, S184.

115. Berg, A.K.; Korsgren, O.; Frisk, G. Induction of the chemokine interferon-gamma-inducible protein-10 in human pancreatic islets during enterovirus infection. Diabetologia 2006, 49, 2697-2703. [CrossRef]

116. Christen, U.; McGavern, D.B.; Luster, A.D.; von Herrath, M.G.; Oldstone, M.B. Among CXCR3 chemokines, IFN-gamma-inducible protein of $10 \mathrm{kDa}$ (CXC chemokine ligand (CXCL) 10) but not monokine induced by IFN-gamma (CXCL9) imprints a pattern for the subsequent development of autoimmune disease. J. Immunol. 2003, 171, 6838-6845. [CrossRef]

117. Richer, M.J.; Lavallee, D.J.; Shanina, I.; Horwitz, M.S. Toll-like receptor 3 signaling on macrophages is required for survival following coxsackievirus B4 infection. PLoS ONE 2009, 4, e4127. [CrossRef]

118. McCartney, S.A.; Vermi, W.; Lonardi, S.; Rossini, C.; Otero, K.; Calderon, B.; Gilfillan, S.; Diamond, M.S.; Unanue, E.R.; Colonna, M. RNA sensor-induced type I IFN prevents diabetes caused by a beta cell-tropic virus in mice. J. Clin. Investig. 2011, 121, 1497-1507. [CrossRef]

119. Wong, F.S.; Hu, C.; Zhang, L.; Du, W.; Alexopoulou, L.; Flavell, R.A.; Wen, L. The role of Toll-like receptors 3 and 9 in the development of autoimmune diabetes in NOD mice. Ann. N. Y. Acad. Sci. 2008, 1150, 146-148. [CrossRef]

120. McCall, K.D.; Thuma, J.R.; Courreges, M.C.; Benencia, F.; James, C.B.; Malgor, R.; Kantake, N.; Mudd, W.; Denlinger, N.; Nolan, B.; et al. Toll-like receptor 3 is critical for coxsackievirus B4-induced type 1 diabetes in female NOD mice. Endocrinology 2015, 156, 453-461. [CrossRef]

121. Gulden, E.; Chao, C.; Tai, N.; Pearson, J.A.; Peng, J.; Majewska-Szczepanik, M.; Zhou, Z.; Wong, F.S.; Wen, L. TRIF deficiency protects non-obese diabetic mice from type 1 diabetes by modulating the gut microbiota and dendritic cells. J. Autoimmun. 2018, 93, 57-65. [CrossRef] [PubMed]

122. Sebastiani, G.; Spagnuolo, I.; Patti, A.; Grieco, F.A.; Cataldo, D.; Ferretti, E.; Tiberti, C.; Dotta, F. MicroRNA expression fingerprint in serum of type 1 diabetic patients. Diabetologia 2012, 55, S48.

123. O'Neill, L.A.; Sheedy, F.J.; McCoy, C.E. MicroRNAs: The fine-tuners of Toll-like receptor signalling. Nat. Rev. Immunol. 2011, 11, 163-175. [CrossRef] [PubMed]

124. Storling, J.; Pociot, F. Type 1 diabetes candidate genes linked to pancreatic islet cell inflammation and beta-cell apoptosis. Genes 2017, 8, 72. [CrossRef] [PubMed]

125. Nyaga, D.M.; Vickers, M.H.; Jefferies, C.; Perry, J.K.; O'Sullivan, J.M. Type 1 diabetes mellitus-associated genetic variants contribute to overlapping immune regulatory networks. Front. Genet. 2018, 9, 535. [CrossRef]

126. Looney, B.M.; Xia, C.Q.; Concannon, P.; Ostrov, D.A.; Clare-Salzler, M.J. Effects of type 1 diabetes-associated IFIH1 polymorphisms on MDA5 function and expression. Curr. Diabetes Rep. 2015, 15, 96. [CrossRef]

127. Kallionpaa, H.; Elo, L.L.; Laajala, E.; Mykkanen, J.; Ricano-Ponce, I.; Vaarma, M.; Laajala, T.D.; Hyoty, H.; Ilonen, J.; Veijola, R.; et al. Innate immune activity is detected prior to seroconversion in children with HLA-conferred type 1 diabetes susceptibility. Diabetes 2014, 63, 2402-2414. [CrossRef]

128. Coppieters, K.T.; Dotta, F.; Amirian, N.; Campbell, P.D.; Kay, T.W.; Atkinson, M.A.; Roep, B.O.; von Herrath, M.G. Demonstration of islet-autoreactive CD8 T cells in insulitic lesions from recent onset and long-term type 1 diabetes patients. J. Exp. Med. 2012, 209, 51-60. [CrossRef]

129. Colli, M.L.; Moore, F.; Gurzov, E.N.; Ortis, F.; Eizirik, D.L. MDA5 and PTPN2, two candidate genes for type 1 diabetes, modify pancreatic beta-cell responses to the viral by-product double-stranded RNA. Hum. Mol. Genet. 2010, 19, 135-146. [CrossRef]

130. Domsgen, E.; Lind, K.; Kong, L.; Huhn, M.H.; Rasool, O.; van Kuppeveld, F.; Korsgren, O.; Lahesmaa, R.; Flodstrom-Tullberg, M. An IFIH1 gene polymorphism associated with risk for autoimmunity regulates canonical antiviral defence pathways in Coxsackievirus infected human pancreatic islets. Sci. Rep. 2016, 6, 39378. [CrossRef]

131. Duan, S.; Paulson, J.C. Siglecs as immune cell checkpoints in disease. Annu. Rev. Immunol. 2020, 38, 365-395. [CrossRef] [PubMed] 
132. Crocker, P.R.; Paulson, J.C.; Varki, A. Siglecs and their roles in the immune system. Nat. Rev. Immunol. 2007, 7, 255-266. [CrossRef] [PubMed]

133. Dharmadhikari, G.; Stolz, K.; Hauke, M.; Morgan, N.G.; Varki, A.; de Koning, E.; Kelm, S.; Maedler, K. Siglec-7 restores beta-cell function and survival and reduces inflammation in pancreatic islets from patients with diabetes. Sci. Rep. 2017, 7, 45319. [CrossRef] [PubMed]

134. Zhao, C.; Zhao, W. TANK-binding kinase 1 as a novel therapeutic target for viral diseases. Expert Opin. Ther. Targets 2019, 23, 437-446. [CrossRef] [PubMed]

135. Zhang, Q.; Meng, F.; Chen, S.; Plouffe, S.W.; Wu, S.; Liu, S.; Li, X.; Zhou, R.; Wang, J.; Zhao, B.; et al. Hippo signalling governs cytosolic nucleic acid sensing through YAP/TAZ-mediated TBK1 blockade. Nat. Cell Biol. 2017, 19, 362-374. [CrossRef]

136. Munoz-Wolf, N.; Lavelle, E.C. Hippo interferes with antiviral defences. Nat. Cell Biol. 2017, 19, $267-269$. [CrossRef]

137. Meng, F.; Zhou, R.; Wu, S.; Zhang, Q.; Jin, Q.; Zhou, Y.; Plouffe, S.W.; Liu, S.; Song, H.; Xia, Z.; et al. Mst1 shuts off cytosolic antiviral defense through IRF3 phosphorylation. Genes Dev. 2016, 30, 1086-1100. [CrossRef]

138. Zhao, B.; Li, L.; Lei, Q.; Guan, K.L. The Hippo-YAP pathway in organ size control and tumorigenesis: An updated version. Genes Dev. 2010, 24, 862-874. [CrossRef]

139. Gao, T.; Zhou, D.; Yang, C.; Singh, T.; Penzo-Mendez, A.; Maddipati, R.; Tzatsos, A.; Bardeesy, N.; Avruch, J.; Stanger, B.Z. Hippo signaling regulates differentiation and maintenance in the exocrine pancreas. Gastroenterology 2013, 144, 1543-1553, 1553.e1. [CrossRef]

140. George, N.M.; Boerner, B.P.; Mir, S.U.; Guinn, Z.; Sarvetnick, N.E. Exploiting Expression of Hippo effector, yap, for expansion of functional islet mass. Mol. Endocrinol. 2015, 29, 1594-1607. [CrossRef]

141. Kulkarni, R.N.; Mizrachi, E.B.; Ocana, A.G.; Stewart, A.F. Human beta-cell proliferation and intracellular signaling: Driving in the dark without a road map. Diabetes 2012, 61, 2205-2213. [CrossRef] [PubMed]

142. Yuan, T.; Rafizadeh, S.; Azizi, A.; Lupse, B.; Gorrepati, K.; Awal, S.; Oberholzer, J.; Maedler, K.; Ardestani, A. Proproliferative and antiapoptotic action of exogenously introduced YAP in pancreatic $\beta$ cells. JCI Insight 2016, 1, e86326. [CrossRef] [PubMed]

143. Blodgett, D.M.; Nowosielska, A.; Afik, S.; Pechhold, S.; Cura, A.J.; Kennedy, N.J.; Kim, S.; Kucukural, A.; Davis, R.J.; Kent, S.C.; et al. Novel observations from Next-generation RNA sequencing of highly purified human adult and fetal islet cell subsets. Diabetes 2015, 64, 3172-3181. [CrossRef] [PubMed]

144. Benner, C.; van der Meulen, T.; Caceres, E.; Tigyi, K.; Donaldson, C.J.; Huising, M.O. The transcriptional landscape of mouse beta cells compared to human beta cells reveals notable species differences in long non-coding RNA and protein-coding gene expression. BMC Genom. 2014, 15, 620. [CrossRef]

145. Pullen, T.J.; Khan, A.M.; Barton, G.; Butcher, S.A.; Sun, G.; Rutter, G.A. Identification of genes selectively disallowed in the pancreatic islet. Islets 2010, 2, 89-95. [CrossRef]

146. Pullen, T.J.; Huising, M.O.; Rutter, G.A. Analysis of purified pancreatic islet beta and alpha cell transcriptomes reveals 11beta-hydroxysteroid dehydrogenase (Hsd11b1) as a novel disallowed gene. Front. Genet. 2017, 8, 41. [CrossRef]

147. Ardestani, A.; Paroni, F.; Azizi, Z.; Kaur, S.; Khobragade, V.; Yuan, T.; Frogne, T.; Tao, W.; Oberholzer, J.; Pattou, F.; et al. MST1 is a key regulator of beta cell apoptosis and dysfunction in diabetes. Nat. Med. 2014, 20, 385-397. [CrossRef]

148. Dunne, J.L.; Richardson, S.J.; Atkinson, M.A.; Craig, M.E.; Dahl-Jorgensen, K.; Flodstrom-Tullberg, M.; Hyoty, H.; Insel, R.A.; Lernmark, A.; Lloyd, R.E.; et al. Rationale for enteroviral vaccination and antiviral therapies in human type 1 diabetes. Diabetologia 2019, 62, 744-753. [CrossRef]

149. Maedler, K.; Oberholzer, J.; Bucher, P.; Spinas, G.A.; Donath, M.Y. Monounsaturated fatty acids prevent the deleterious effects of palmitate and high glucose on human pancreatic beta-cell turnover and function. Diabetes 2003, 52, 726-733. [CrossRef]

150. Halban, P.A.; Polonsky, K.S.; Bowden, D.W.; Hawkins, M.A.; Ling, C.; Mather, K.J.; Powers, A.C.; Rhodes, C.J.; Sussel, L.; Weir, G.C. beta-cell failure in type 2 diabetes: Postulated mechanisms and prospects for prevention and treatment. Diabetes Care 2014, 37, 1751-1758. [CrossRef]

151. Herold, K.C.; Bundy, B.N.; Long, S.A.; Bluestone, J.A.; DiMeglio, L.A.; Dufort, M.J.; Gitelman, S.E.; Gottlieb, P.A.; Krischer, J.P.; Linsley, P.S.; et al. An anti-CD3 antibody, teplizumab, in relatives at risk for type 1 diabetes. N. Engl. J. Med. 2019, 381, 603-613. [CrossRef] [PubMed] 
152. Cabrera, S.M.; Wang, X.; Chen, Y.G.; Jia, S.; Kaldunski, M.L.; Greenbaum, C.J.; Type 1 Diabetes Trialnet Canakinumab Study Group; Mandrup-Poulsen, T.; AIDA Study Group; Hessner, M.J. Interleukin-1 antagonism moderates the inflammatory state associated with Type 1 diabetes during clinical trials conducted at disease onset. Eur. J. Immunol. 2016, 46, 1030-1046. [CrossRef] [PubMed]

153. Ardestani, A.; Li, S.; Annamalai, K.; Lupse, B.; Geravandi, S.; Dobrowolski, A.; Yu, S.; Zhu, S.; Baguley, T.D.; Surakattula, M.; et al. Neratinib protects pancreatic beta cells in diabetes. Nat. Commun. 2019, 10, 5015. [CrossRef] [PubMed]

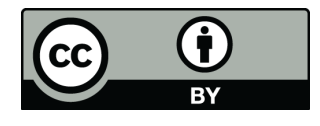

(C) 2020 by the authors. Licensee MDPI, Basel, Switzerland. This article is an open access article distributed under the terms and conditions of the Creative Commons Attribution (CC BY) license (http://creativecommons.org/licenses/by/4.0/). 